\title{
T. LEBEDENKO
}

\section{METHOD OF SCHEDULING AND ACTIVE QUEUES MANAGEMENT ON ROUTERS INTERFACES OF TELECOMMUNICATION NETWORKS}

The subject matter of the article is the method of scheduling and active queues management on routers interfaces of telecommunication networks. The goal of the work is to develop and improve the method related to the optimization of queues management processes on routers interfaces of telecommunication networks and aimed at improving the indicators of the quality of service. The article solves optimization problems of Congestion Management, Resource Allocation and Congestion Avoidance on routers interfaces of telecommunication networks in the framework of the two-stage calculation method. Research methods are based on the results of analytical calculations obtained in the course of using the Optimization Toolbox package of the Mat lab environment. Wherein in the course of improving the queue management method on routers interfaces of telecommunication networks, a mathematical programming apparatus was used, containing linear programming functions. The following results were obtained - the improved method of scheduling and active queues management on routers interfaces of telecommunication networks with the coordinated, sequential and two-stage solution of such interface problems as Congestion Management, Resource Allocation, and Congestion Avoidance. Conclusions: using the proposed method of scheduling and active queue management had made to achieve an agreed solution to Congestion Management, Resource Allocation, and Congestion Avoidance problems. In the course of solving the optimization problem of Congestion Management, which was conditionally related to the first stage of calculations, it was possible to achieve optimal aggregation and allocation of packet flows over queues formed on the router interface based on the commensurability of their classes. In the course of solving the optimization problems of resource allocation, and congestion avoidance, which were conditionally related to the second stage of calculations, it was possible to achieve an optimal bandwidth allocation of the router interface between the queues formed on it, and minimize possible denials of service.

Keywords: active queues management; congestion management; resource allocation; congestion avoidance; bandwidth; router interface; telecommunication network; quality of service.

\section{Introduction}

Providing users with the high quality of service (QoS) is one of the most important requirements for the advanced telecommunication networks (TCN) [1-5]. In this case, improving the numerical values of QoS indicators such as average delay, jitter, and probability of packet loss are largely dependent on the effectiveness of planning methods and active queue management. The queuing scheduling methods mean the solution of such interface tasks as:

- the task of congestion management (Congestion Management), which involves the distribution and aggregation of packet flows between queues formed on the router interface;

- the task of distributing the bandwidth of the interface between the formed queues (Resource Allocation).

The solution to the problem of preventing overload (Congestion Avoidance), which aims to provide a preventive (advance) limitation of the intensity of packet flows arriving at the interface TCN router [6-10], is understood as the methods of active queue management (AQM).

An overview of existing mathematical models and queuing techniques on TCN routers interfaces has identified a list of requirements for their effective implementation, among which:

- provision of differentiation in maintenance of flows of packages of different classes;

- fairness in service (that is, the ability of models and methods to provide service flow packets in accordance with their QoS requirements);

- adaptability and scalability (that is, the ability of models and methods to automatically change their characteristics depending on the change in the intensity of traffic, the number of packets received on the interface of the router, etc.);

- reliability (i.e. the ability of models and methods to continue to function in case of possible overload or even partial failure of equipment);

- support of a dynamic queuing strategy (i.e., the ability of models and methods to find the correct solution for managing queues in real-time);

- simplicity of algorithmic-software and hardware implementation, low computational complexity.

However, the analysis of the known queue management solutions on TCN routers interfaces showed that the satisfaction of the listed requirements within one method and / or model has not yet been implemented in practice. Thus, in $[11,12,17,18]$, mathematical models of queue management on interfaces of TCN routers are presented on the basis of optimal aggregation and distribution of flows by queues. The advantage of these models is to take into account the dynamics of changing the state of the interface of the router in the distribution of the network resource due to the additionally introduced dynamically controlled threshold load $[11,12,17]$ and the application of the approximation of PSFFA [18]. The general disadvantage of these models is the lack of conditions associated with minimizing the bandwidth usage of the interface and fixing its shares in separate queues. In [14], an approach to the optimal solution of the Resource Allocation problem was proposed using the Mean Opinion Score (MOS), their application to the Nash Bargaining Solution, and the subsequent reduction of the obtained conditions to the minimal problem resource allocation. The disadvantage of this work is the lack of differentiation and fairness in serving traffic flows with different QoS requirements. [15, 16, 20-22] presents mathematical models and queuing control methods that 
combine both queuing planning methods and active queuing methods. The main disadvantage of these models and methods is the high dimension of optimization tasks, which leads to an increase in the computational complexity of obtaining the desired solutions and complication of their subsequent algorithmic-software implementation. In this regard, the scientific and applied task of developing mathematical models and methods related to the optimization of the queue management process on the interfaces of TCN routers seems to be relevant due to providing a comprehensive solution to queue planning problems - Congestion Management, Resource Allocation, and active queue management Congestion Avoidance.

\section{Queuing Planning Model on Interfaces of Telecommunication Routers and Overload Management Task solving}

Based on the results obtained in [11, 12, 15, 20-22], a method for planning and active queue management on the interfaces of telecommunication network routers with the successive solution of overload control optimization tasks, the allocation of bandwidth of the interface and prevention of overload [12] is proposed. The analysis of known solutions for the joint solution of the Congestion Management, Resource Allocation and Congestion Avoidance problems presented in [21, 22] demonstrated that the results of the solution to the overload management problem are not related to the results of the solution of the problem of the allocation of bandwidth of the interface and prevention tasks overload. Consequently, a shared or distributed solution to these tasks will result in the same result. Thus, in order to reduce the dimension of optimization tasks, a two-step method of calculation is proposed, where the first stage will correspond to the solution of the Congestion Management (queuing model), while the second one is for Resource Allocation and Congestion Avoidance (active queuing model).

Then, let us at the first stage of the calculations, to the input of the interface of the router there are $N$ flows of packets with the following known characteristics:

$a_{i} \quad(i=\overline{1, N})$ - the average intensity of the $i$-th flow of packets, which is measured in packets per second $(1 / \mathrm{c})$;

$k_{i}^{f} \quad(i=\overline{1, N})$ - the value of the class of the $i$-th flow of packets. The higher is the value $k_{i}^{f}$, so with the higher QoS it should be served on the router interface;

$K$ - the maximum value of the packet flows class.

Let us agree that within the scope of this work, the value of the class of the flows $k_{i}^{f}$ will be quantified by a real number, which varies from 1 to $K$, that is, the condition $1 \leq k_{i}^{f} \leq K$ will take place. Differentiation of flows of packages of different classes is possible in accordance with the following features $[4,5]$ :

- content of the IP packet fields: IP-precedence or DSCP;

- Value of the QoS-group;

- Address of the source of the IP packet;

- Address of the recipient of the IP-packet;
- MAC addresses of the source and (or) recipient of the packets;

- Standard or extended list of access to sources / recipients;

- TCP / UDP port of the source and / or packet recipient;

Package length code.

In the general case, by analogy with $[11,12]$, the classes of packet flows $k_{i}^{f}$ can be represented as some nonlinear function of the form:

$$
k_{i}^{f}\left(p_{i}, l_{i}\right)=\frac{p_{i}}{v \cdot l_{i}}, \quad(i=\overline{1, N}),
$$

where $p_{i}$ - priority of the $i$-th packet-flow; $l_{i}$ - average packet length of the $i$-th flow; $v$ - the normalization coefficient, which allows to smooth the difference in the order of the values of priority $(0 \div 7)$ and the packet length in bytes.

In addition, according to works [17-19], it is possible to determine the flow classes using the analog of the IGPP (Internal Gateway Routing Protocol) routing metric:

$$
k_{i}^{f}=v\left[K_{1} Q_{i}^{b}+K_{2} Q_{i}^{\tau}\right] \frac{K_{3}}{Q_{i}^{r}+K_{4}},
$$

where $v$ - the normalization coefficient introduced to ensure the condition $1 \leq k_{i}^{f} \leq 10 ; \quad K_{1}, K_{2}, K_{3}, K_{4} \quad-$ coefficients that determine the influence of a QoS indicator on the flow class and are set administratively; $Q_{i}^{b}, Q_{i}^{\tau}, Q_{i}^{r}-$ values that characterize the QoS-specific indicators, including: $Q_{i}^{b}$ - the value that is inverse to the requirements for the bandwidth of the $i$-th flow; $Q_{i}^{\tau}-$ a value that characterizes the requirements for the average delay of packets of the $i$-th flow; $Q_{i}^{r}$ - the value that determines the required level of reliability of packets delivery of the $i$-th flow.

The use (2) in solving problems of distribution of packet flows on the lines formed on the interface of the router allows for explicit consideration of requirements for the quality of service and the implementation of aggregation of flows according to the received classes.

Packets $N$ flows that are received for maintenance on the interface of the router TCN must be distributed among the $M$-queues created on it during the solution of the task of overload management (Congestion Management task) by calculating the set of variables of the first type $x_{i, j}$ $(i=\overline{1, N}, j=\overline{1, M})$, each of which characterizes the part of the $i$-th packet flow, aimed for servicing at the $j$-th turn [20-22]. Under the value $M$ we will keep in mind the maximum number of queues that can be arranged on the router interface according to the existing congestion management mechanisms such as FIFO, PQ, CQ, FQ / WFQ, CBWFQ, LLQ [1-3].

We will assume that by analogy with the classification of packet flows $k_{i}^{f}$, the classification of the 
queues itself $k_{j}^{q} \quad(j=\overline{1, M})$ is also established, where the value of the class of $j$-th queue corresponds to the condition $1 \leq k_{j}^{q} \leq K$. The criterion for directing a differentiated stream of packets in one way or another will be the maximum coincidence of the values of classes $k_{i}^{f}$ and $k_{j}^{q}$. Aggregation of packet flows in the corresponding queues will only be relevant if the condition $N>M$ is fulfilled, that is, when the number of queue-supported router interfaces supported is less than the number of packet flows arriving at its input

In order to ensure the fulfillment of the conditions for the differentiation of service flow packets with different QoS requirements, it is proposed to process packet flows with close values of classes $k_{i}^{f}$ within the framework of one of the queues formed on the router's interface, and determine the control variables of the first type $x_{i, j}$ as boolean:

$$
x_{i, j}=\{0,1\} .
$$

The calculation of control variables of the first type $x_{i, j}$ is advisable in the solution of the optimization problem Congestion Management, which involves the aggregation and distribution of packet flows based on queues formed on the router interface $[10,11,22]$ :

$$
\min _{x} F \text {, }
$$

where $F$ - target function, represented by the form of the type:

$$
F=\sum_{i=1}^{N} \sum_{j=1}^{M} h_{i, j}^{x} x_{i, j}
$$

$h_{i, j}^{x}-$ conditional cost (metric) of package service of the $i$-th flow-at the $j$-th-turn:

$$
h_{i, j}^{x}=\left(k_{i}^{f}-k_{j}^{q}\right)^{2}+1, \quad(i=\overline{1, N}, j=\overline{1, M}) .
$$

Metric $h_{i, j}^{x}$ is a positive value, the value of which (5) depends directly on the square of the distance between the classes of individual streams and queues [17-22]. The closer are the values $k_{i}^{f}$ and $k_{j}^{q}$, the smaller is the service metric $h_{i, j}^{x}$. If the class values $\left(k_{i}^{f}=k_{j}^{q}\right)$ are the same, the service metric will be minimal and will be equal to one $\left(h_{i, j}^{x}=1\right)$. Thus, the maximum proximity of the values $k_{i}^{f}$ and $k_{j}^{q}$ will guarantee the direction of the packet-flow for service to the $i$-th turn. Consequently, the use of the target function (4) taking into account the metric (5) and the presence of the restriction (3) determines the optimization task of the first level of calculations as an optimization problem of Boolean programming, the solution of which is to determine the optimal order of distribution and aggregation of packet flows between the formed queues based on commensurability of their classes, which fully meets the technological requirements of the Congestion Management task.

\section{Model of active queue management on interfaces of telecommunication network routers and solution of bandwidth allocation and overload prevention tasks}

The second stage of the calculations is a coherent solution to the tasks of allocating the bandwidth of the interface between the formed queues and preventing overload [12-14, 22]. The transition to the second stage occurs after solving the optimization problem for aggregation and distribution of packet flows based on queues formed on the router interface, when the result of the calculation of the set of control variables $x_{i, j}$ is already known. Then, to solve the Resource Allocation problem, we introduce a set of control variables of the second type $b_{j}(j=\overline{1, M})$, each of which defines the fraction of the bandwidth of the interface allocated for service of $j$-th queue. To ensure the correctness of the distribution of the overall bandwidth of the interface $-b$ between the specific queues, the variables $b_{j}$ must be imposed the conditions:

$$
b_{j} \geq 0, \quad \sum_{j=1}^{M} b_{j} \leq b, \quad(j=\overline{1, M}) .
$$

For the possibility of implementing a preventive (advance) limitation of the intensity of the flows received on the input of the interface of the router of the telecommunication network, it is also necessary to introduce a set of variables of the third type $y_{i}(i=\overline{1, N})$, which in their physical content characterize the part of a $i$-th flow of packets that was refused service on the interface of the router during the solution of the problem of Congestion Avoidance [20, 21]. Numerically, the variables $y_{i}$ will determine the probability of dropping the packets of the $i$-th flow from the $j$-th queue formed at the router's interface and will be subject to the condition of the form:

$$
0 \leq y_{i} \leq 1,(i=\overline{1, N})
$$

In order to ensure controllability of the process of preventing overloading the TCN router interface, it is necessary to satisfy a non-linear constraint that ensures that the total intensity of $-i$-th flows directed to service in $j$-th queue will in no case exceed the bandwidth of the interface allocated in this queue:

$$
\sum_{i=1}^{N} a_{i} x_{i, j}\left(1-y_{i}\right) \leq b_{j},(j=\overline{1, M})
$$

Condition (8) reflects the functional interaction between control variables of all three types, linking the optimization tasks of the first and second stages of the calculations. Satisfaction (8) guarantees that the aggregate intensity of the already known aggregated according to metric (5), packet streams will not cause overloading of the routine formed on the interface of the TCN queues due 
to the implementation of the functions of Congestion Avoidance and Resource Allocation.

Based on the formulated conditions and constraints (6) - (8), the calculation of the required variables $b_{j}$ and

$y_{i}$ conditionally related to the second stage of calculations, it is expedient to implement in the course of solving the next optimization problem:

$$
\begin{gathered}
\min _{b, y} P, \\
P=\sum_{j=1}^{M} h_{j}^{b} b_{j}+\sum_{i=1}^{N} h_{i}^{y} a_{i} y_{i},
\end{gathered}
$$

where $h_{j}^{b}$ - the nominal value (metric), which is responsible for allocating the bandwidth unit of the router interface to packets from the $j$-th queue; $h_{i}^{y}$ - Conditional cost (metric), which is responsible for refusals to service packets of the i-th flow.

The result of solving an optimization task with the target function (9) will be related to minimizing the use of bandwidth of the interface of the router due to its optimal distribution, and minimizing possible service failures caused by preventive (advance) flow limitation.

Similar to metric (5), metrics $h_{j}^{b}$ and $h_{i}^{y}$ depend on values of classes of streams $k_{i}^{f}$ and queues $k_{j}^{q}$. Moreover, the higher is the class $k_{j}^{q}$, the greater is the value $h_{j}^{b}$ and the greater the bandwidth of the interface will be allocated to the $j$-th queue. Increasing the class $k_{i}^{f}$ also leads to an increase in the value of the metric $h_{i}^{y}$, and the larger the values of this metric; the fewer packets will receive denial of service. Consequently, the higher the values of the classes of flows and queues, the more expensive are refusals to service the packets of the $i$-th flow that came to the $j$-th queue.

The fulfillment of the conditions (6) - (8) during the solution of the optimization problem (9) allows the optimal allocation of the bandwidth of the TCN router interface between the generated queues and provides a preventive limitation of the packet stream intensity by analogy with overload prevention mechanisms (RED, WRED) due to the possibility flexible regulation of the direction of one or another stream to those or other queues.

Thus, the basis of the method of planning and active queue management on the interfaces of telecommunication network routers is a consistent and two-stage solution to the following interface tasks:

- an optimization task for overload management with a target function (4) and a limitation (3) whose purpose is to optimally allocate and aggregate packet streams between queues formed on the router interface based on the summation of values of the classes of flows and queues represented by the metric (5);

- problems of the optimal allocation of bandwidth of the interface between the formed queues and the task of preventing the overload of the interface presented by the optimization form with the target function (9) and restrictions (6), (7).

The general structure of the method of planning and active queue management on the interfaces of telecommunication network routers is shown in fig. 1.

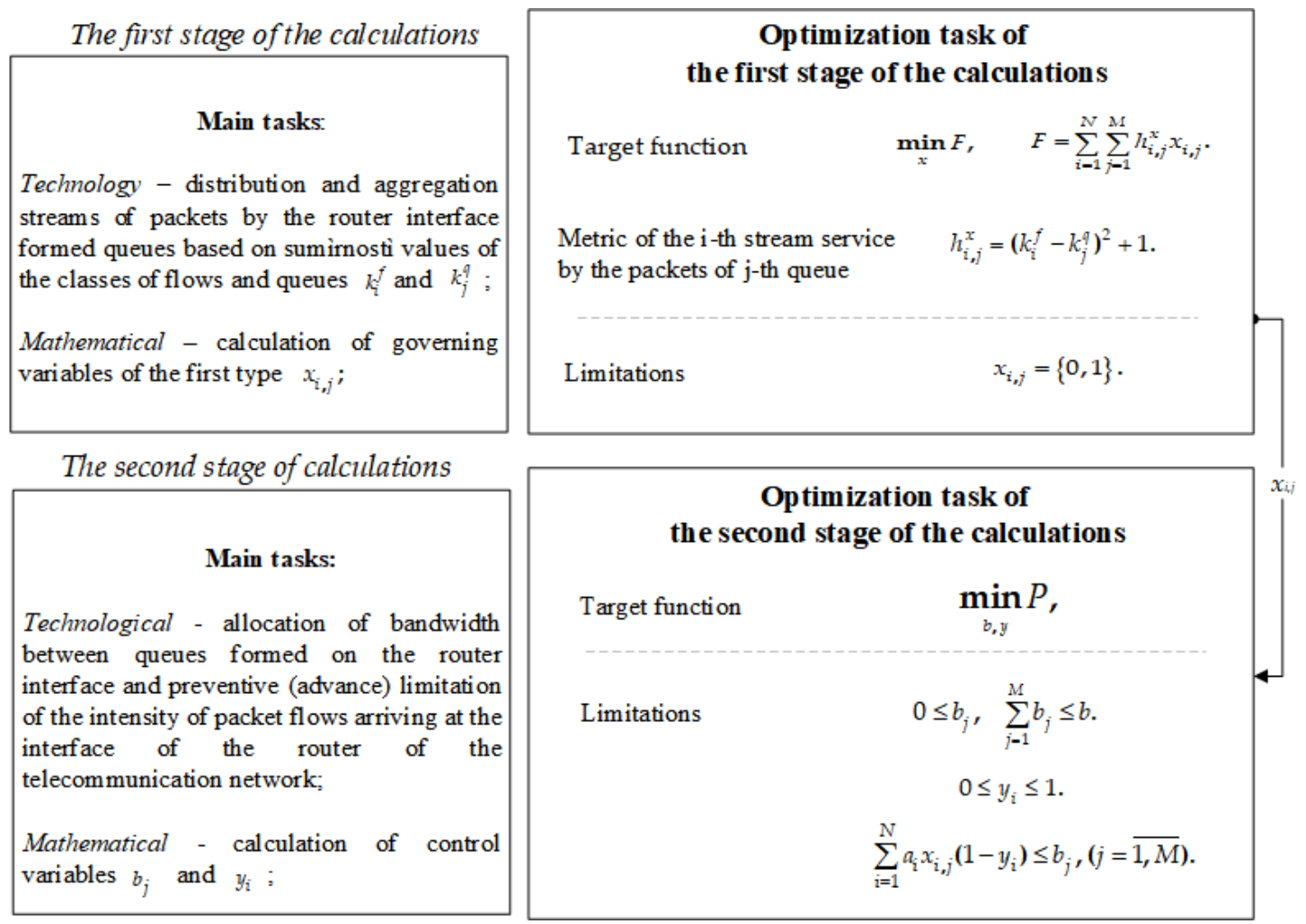

Fig. 1. Structure of the method of planning and active queue management on interfaces of telecommunication network routers 
Investigation of the method of planning and active queue management on interfaces of telecommunication network routers

The study of the proposed planning method and active queue management on the interfaces of telecommunication network routers was based on the analytical calculations obtained during the use of Mat lab's Optimization Toolbox package when solving the optimization problems of Congestion Management, Resource Allocation and Congestion Avoidance [23, 24].

Fig. 2 shows the initial data and calculation results for the first example. Let, in this example, the traffic that came to the interface of the router consisted of twelve streams. The value of the classes and the intensities of the flows $k_{i}^{f}$ were given randomly. The streaming differentiation was carried out, for example, based on the content of the IP packet fields: IP Precedence, with the maximum value of stream classes. Serving flows was carried out in four queues $(M=4)$. Let us suppose also that the interface of the router was overloaded, that is, condition (8) was not executed. Moreover, the total intensity of streams in queues was $113.99351 / \mathrm{s}$, while the bandwidth of the interface $-1 / \mathrm{s}$.

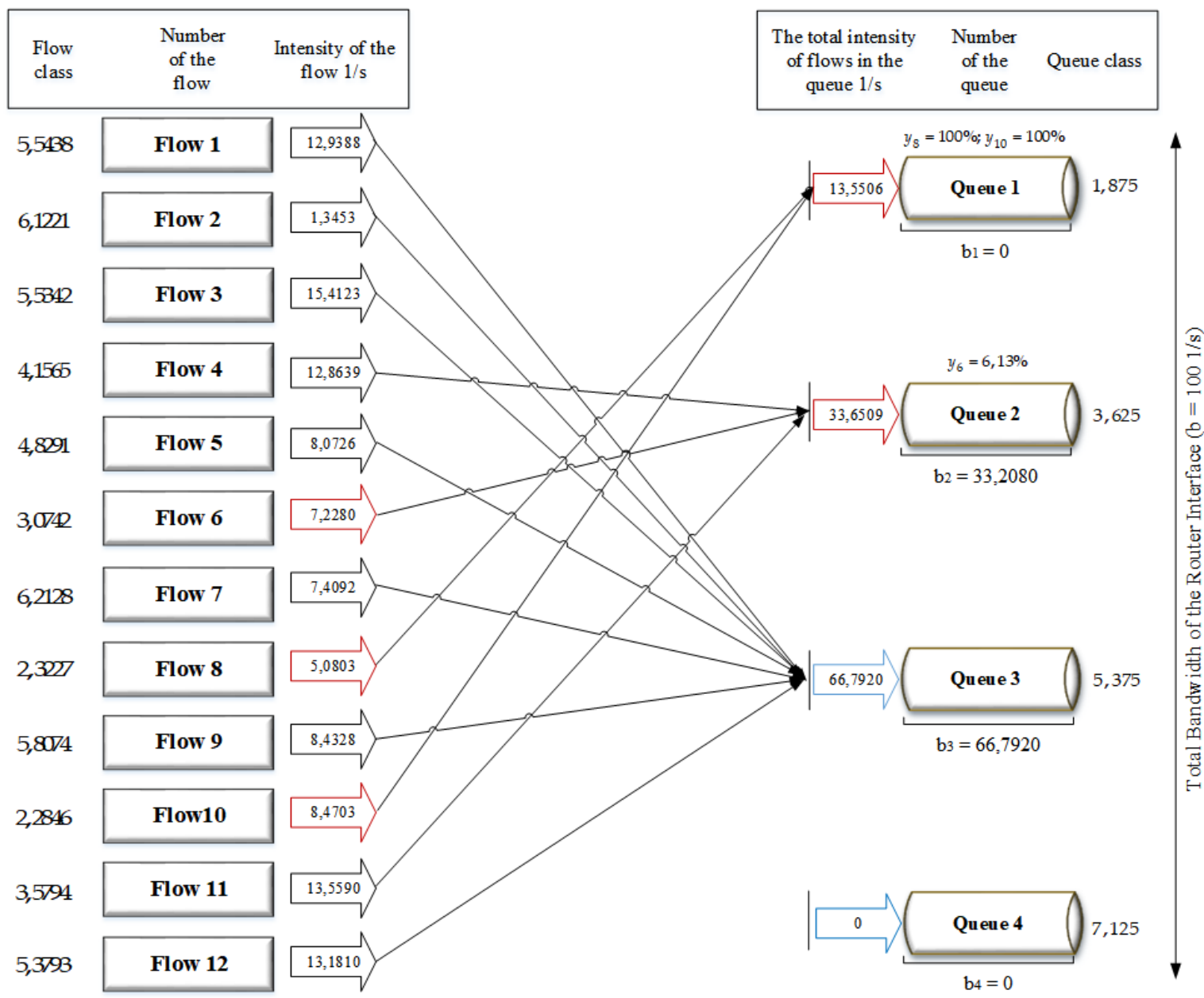

Fig. 2. Output and calculation results for the first example using the target function of the linear form (9) and in the conditions of the overload of the interface of the router

According to the analytical calculations presented in fig. 2 it was able to confirm the correctness of the solution of the optimization problem of the first stage of calculations (4) regarding the aggregation of packet flows and their subsequent distribution in corresponding queues based on the proximity of the values of classes $k_{i}^{f}$ and $k_{j}^{q}$. In addition, the correctness of the decision of the tasks of the second stage of calculations (9) in the conditions of the overload of the interface of the router was analyzed. In fig. 2, it can be seen that using the linear target function (9), the threads with the lowest values of classes $\left(k_{8}^{f}=2,3227\right)$ and $\left(k_{10}^{f}=2,2846\right)$ those that were directed to the low-order queue $\left(k_{1}^{q}=1,875\right)$, received restrictions on maintenance until the complete refusal in it. The probability of dropping packets from the eighth and tenth streams was equal to one. At the same time, flows with high values of classes were not limited to serving as long as it was possible to deny flows with low values.

In the second example, during the study of the proposed method case was considered for similar output data, but in the absence of overload interface router - fig. 3. That is, in conditions where the total intensity of streams in queues is equal to $77.11221 / \mathrm{s}$, and the bandwidth of the interface is $1 / \mathrm{s}$. 


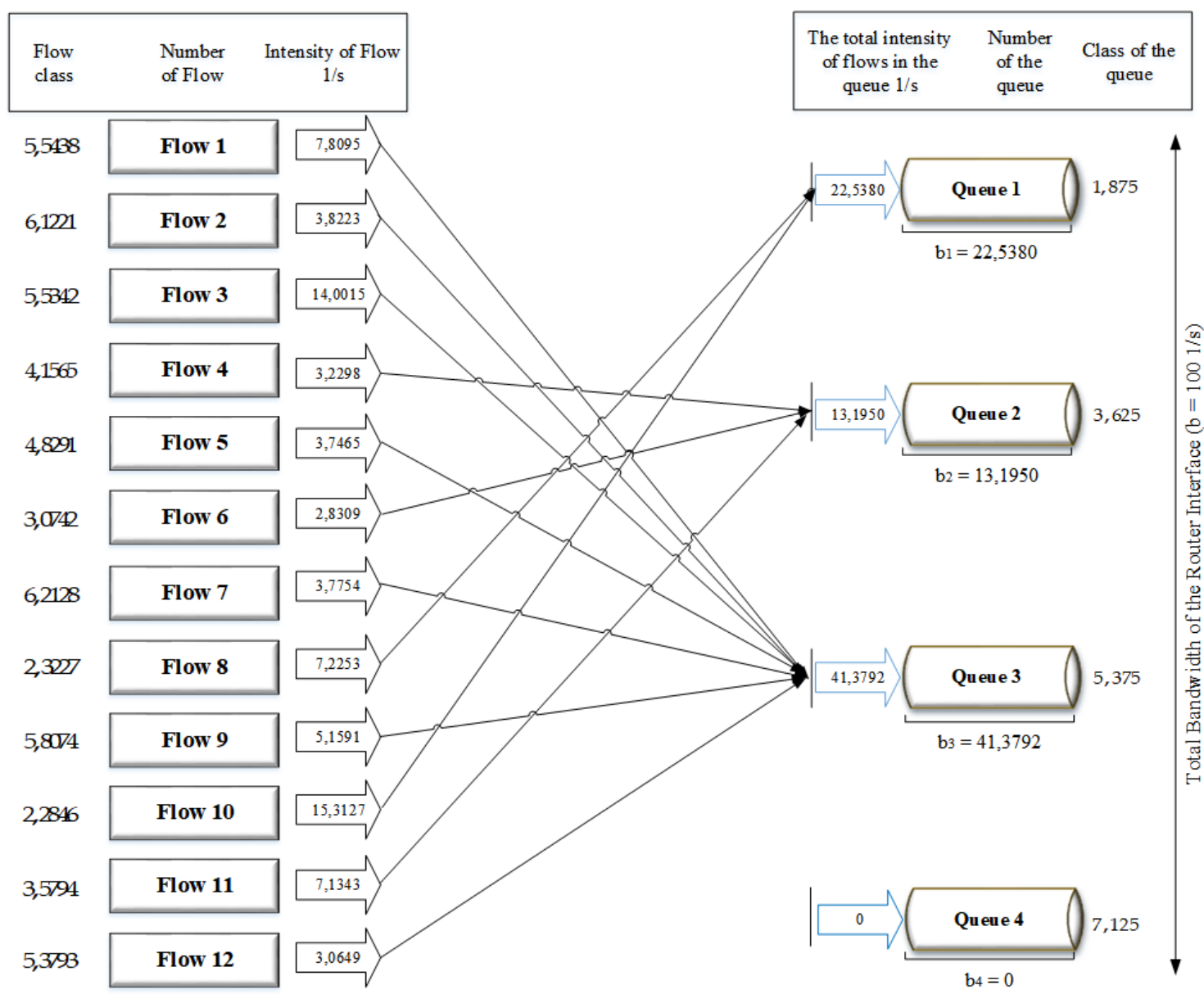

Fig. 3. Output and calculation results for the second example using the target function of the linear form (9) provided there is no overload of the interface of the router

In the second example, shown in fig. 3 also succeeded in confirming the correctness of the aggregation and distribution of packet flows in the generated queues based on the summation of the values of their classes. The results of the study showed that, in the absence of overloading the interface of the router, none of the packet flows received a denial of service and the use of the linear target function (9) was sufficient to achieve the optimal allocation of bandwidth of the router interface between the formed queues and minimize possible service failures (fig. 3). Another advantage of the presentation of the optimization problem by the objective function of the linear form (9) was a small computational complexity, which made it possible to simplify its technological implementation.

\section{Conclusions}

The paper proposes a method of planning and active queue management on interfaces of telecommunication network routers. The novelty of this method was the approach to successive two-stage solution of such interface tasks as:

- the task of controlling overloads, the purpose of which was optimal aggregation and distribution of packet flows based on queues formed on the interface of the router in accordance with the equivalence of values of classes of flows and queues;

- the problem of optimal allocation of the bandwidth of the interface between the queues formed on it;

- the task of preventing overload, the purpose of which was to provide a preventive (timely) limitation of the intensity of packet flows arriving at the interface of the router of the telecommunication network.

The analysis of known solutions [4, 5, 10-22] has shown that the results of the solution of the Congestion Management problem are not related to the results of the Resource Allocation and Congestion Avoidance tasks. That is why, in order to reduce the computational complexity of the calculations of the optimization problems, their distributed solution was proposed within the framework of the two-step method (fig. 1).

Investigating overload management processes, distributing bandwidth and preventing overloads confirmed the effectiveness of the proposed planning method and active queue management. However, it should be noted that the correctness and adequacy of the solutions it receives using the target function of the linear form (9) is achieved only if there is no overload of the interface of the router. Therefore, further development of this method is seen in the use of quadratic and linear quadratic target functions to provide a more equitable solution to the Resource Allocation and Congestion Avoidance. 


\section{References}

1. Marsic, I. (2013), Computer Networks: Performance and Quality of Service, Rutgers University, 500 p.

2. Rao, S. S. (2019), Engineering Optimization: Theory and Practice, John Wiley \& Sons, 5th Edition, 880 p.

3. Barreiros, M., Lundqvist, P. (2016), QOS-Enabled Networks: Tools and Foundations, Wiley Series on Communications Networking \& Distributed Systems, Wiley, 2nd Edition, 254 p.

4. Szigeti, T., Hattingh, C., Barton, R., Briley, Jr. K. (2013), End-to-End QoS Network Design: Quality of Service for Rich-Media \& Cloud Networks. Cisco Press, 768 p.

5. Rao, D. S. (2012), Queue Management and Quality of Service (QoS) in the Internet: A Novel Approach for Flow Protection for providing Better than Best-Effort Service in the Internet, LAP LAMBERT Academic Publishing, $188 \mathrm{p}$.

6. Smith, J. M. (2009), Introduction to Queueing Networks: Theory $\cap$ Practice, Springer, $562 \mathrm{p}$.

7. Yue, W., Takahashi, Yu., Takagi, H. (2009), Advances in Queueing Theory and Network Applications. Springer, 316 p.

8. Giambene, G. (2014), Queuing Theory and Telecommunications, Springer US, 2nd Edition, 516 p.

9. Kamoun, F., Outay F. (2018), "IP/MPLS Networks with Hardened Pipes: Service Concepts, Traffic Engineering and Design Considerations", Journal of Ambient Intelligence and Humanized Computing, P. 1-8.

10. Lemeshko, A. V., Dobryshkin, Yu. N., Shcherbinin, S. A. (2008), "Investigation of a traffic control model with an analysis of areas of preventive limitation of its intensity at the network boundary" ["Issledovanie modeli upravleniya trafikom s analizom oblastey preventivnogo ogranicheniya ego intensivnosti na granitse seti"], Modelyuvannya ta informacijni texnologiyi, No. 49, P. 6571.

11. Simonenko, A. V., Andrushko, D. V. (2008), "Mathematical model of queue management on telecommunication network routers based on optimal aggregation of flows and packet allocation among queues" ["Matematicheskaya model' upravleniya ocheredyami na marshrutizatorakh telekommunikatsi-onnoy seti na osnove optimal'nogo agregirovaniya potokov i raspredeleniya paketov po ocheredyam"], available at : http://pt.journal.kh.ua/2015/1/1/151_simonenko_queue.pdf (last accessed 23. 05. 2019)

12. Lemeshko, O., Lebedenko, T., Yeremenko, O., Simonenko, O. (2018), "Mathematical Model of Queue Management with Flows Aggregation and Bandwidth Allocation", International Conference on Theory and Applications of Fuzzy Systems and Soft Computing, Springer, Cham, P. 165-176. DOI:10.1007/978-3-319-91008-6_17

13. Tan, L. (2017), Resource Allocation and Performance Optimization in Communication Networks and the Internet, CRC Press, $503 \mathrm{p}$.

14. Fei, Z., Xing, C., Li, N. (2015), "QoE-Driven Resource Allocation for Mobile IP Services in Wireless Network", Science China Information Sciences, No. 1 (58), P. 1-10.

15. Lemeshko, A. V., Semenyaka, M. V. (2012), "Researching of Mathematical Models Based on Optimal Control Approaches for Congestion Control in Telecommunication Network", East-West Design \& Test Symposium (EWDTS'2012): Proceedings of IEEE East-West Design \& Test Symposium (Kharkiv, Ukraine, 14-17 Sept. 2012), Kharkiv, P. 341-344.

16. Okokpujie, K. O., Chukwu, E. C., Noma-Osaghae, E., Okokpujie, I. P. (2018), "Novel Active Queue Management Scheme for Routers in Wireless Networks", International Journal on Communications Antenna and Propagation (I. Re. CAP), No. 8 (1), P. 53 61.

17. Lemeshko, A. V., Semenyaka, M. V. (2014), "Model and method of preventing overloads with active control of the queue length on the telecommunication network nodes" ["Model' i metod predotvrashcheniya peregruzok s aktivnym upravleniem dlinnoy ocheredi na uzlakh telekommunikatsionnoy seti"], available at : http://pt.journal.kh.ua/2014/3/1/123_model_peregruzka.pdf (last accessed 21.11.2018)

18. Lebedenko, T. N., Simonenko, A. V. (2018), "Dynamic model of queues management on router interface of telecommunication network" ["Dinamicheskaya model' upravleniya ocheredyami na interfeyse marshrutizatora telekom-munikatsionnoy seti"], Radioelektronika i informatika, No. 1, P. 13-18.

19. Lemeshko, O. V., Ali, S., Semenyaka, M. V. (2012), "Results of the Dynamic Flow-Based Queue Balancing Model Research", Modern Problems of Radio Engineering Telecommunications and Computer Science (TCSET'2012): Proceedings of the International Conference (Lviv-Slavske, Ukraine, 21-24 Feb. 2012), Lviv, P. 318-319.

20. Lemeshko, A. V., Lebedenko, T. N. (2018), "Linear model of optimal queues management on router interface of telecommunication network" ["Lineynaya model' optimal'nogo upravleniya ocheredyami na interfeyse marshrutizatora telekommunikatsionnoy seti"], Information Content and Processing, Vol. 4, No. 2, P. 171-181.

21. Lebedenko, T., Kholodkova, A., Al-Dulaimi, A. (2018), "Linear-Quadratic Model of Optimal Queue Management on Interface of Telecommunication Network Router", Information and Telecommunication Technologies and Radio Electronics (UkrMiCo'2018): Proceedings of the Third International Conference (Odessa, Ukraine, 10-14 September 2018), Odessa, IEEE, P. 1-4.

22. Lebedenko, T. M., Mokryak, A. A., Symonenko, O. V., Cherkasov, A. V., Vlasenko, A. O. (2018), "Improvement and research of the method of balanced queue management on routers interfaces of telecommunication networks" ["Vdoskonalennya ta doslidzhennya metodu zbalansovanogo upravlinnya chergamy` na interfejsax marshruty`zatoriv telekomunikacijnoyi merezhi"], available at : http://pt.journal.kh.ua/2018/2/1/182_lebedenko_queue.pdf (last accessed 23. 05. 2019)

23. Ploskas, N., Samaras, N. (2017), Linear Programming Using MATLAB ${ }^{\circledR}$ (Springer Optimization and Its Applications), Springer, $637 \mathrm{p}$.

24. Lopez, C. (2014), MATLAB Optimization Techniques, Apress, 292 p.

Received 31.05.2019

Вiдомості про авторів / Сведения об авторах / About the Authors

Лебеденко Тетяна Миколаївна - Харківський національний університет радіоелектроніки, асистент кафедри інфокомунікаційної інженерії ім. В. В. Поповського, Харків, Україна; e-mail: tetiana.lebedenko@nure.ua; ORCID: https://orcid.org/0000-0003-4906-4323. 
Лебеденко Татьяна Николаевна - Харьковский национальный университет радиоэлектроники, ассистент кафедры инфокоммуникационной инженерии им. В. В. Поповского, Харьков, Украина

Lebedenko Tetiana - Kharkiv National University of Radio Electronics, Assistant of the Department of Infocommunication Engineering, Kharkiv, Ukraine.

\section{МЕТОД ПЛАНУВАННЯ ТА АКТИВНОГО УПРАВЛІННЯ ЧЕРГАМИ НА ІНТЕРФЕЙСАХ МАРШРУТИЗАТОРІВ ТЕЛЕКОМУНІКАЦЙНИХ МЕРЕЖ}

Предметом дослідження в роботі $є$ метод планування та активного управління чергами на інтерфейсах маршрутизаторів телекомунікаційних мереж. Метою роботи є розробка та вдосконалення методу, який пов'язаний з оптимізацією процесів управління чергами на інтерфейсах маршрутизаторів телекомунікаційних мереж та орієнтований на підвищення показників рівня якості обслуговування. В роботі вирішуються оптимізаційні задачі управління перевантаженнями, розподілу ресурсів та запобігання перевантаженнями на інтерфейсах маршрутизаторів телекомунікаційних мереж в рамках двоетапного методу розрахунків. Методи дослідження грунтуються на результатах аналітичних розрахунків, що отримані в ході використання пакету Optimization Toolbox середовища Matlab. При цьому в ході вдосконалення методу управління чергами на інтерфейсах маршрутизаторів телекомунікаційних мереж використовувався апарат математичного програмування, що містив функції лінійного програмування. Результати: отримано вдосконалений метод планування та активного управління чергами на інтерфейсах маршрутизаторів телекомунікаційних мереж з узгодженим, послідовним та двоетапним вирішенням таких інтерфейсних задач як управління перевантаженнями (Congestion Management), розподіл пропускної здатності інтерфейсу маршрутизатора (Resource Allocation) та запобігання перевантаження (Congestion Avoidance). Висновки: застосування запропонованого методу планування та активного управління чергами дозволило досягти узгодженого вирішення задач Congestion Management, Resource Allocation та Congestion Avoidance. В ході вирішення оптимізаційної задачі Соngestion Management, що умовно відносилася до першого етапу розрахунків, вдалося досягти оптимальної агрегації та розподілу потоків пакетів по сформованих на інтерфейсі маршрутизатора чергах на основі близькості значень їх класів. При вирішенні оптимізаційних задач Resource Allocation та Congestion Avoidance, що відносилися до другого етапу розрахунків, вдалося досягти оптимального розподілу пропускної здатності інтерфейсу маршрутизатора між сформованими на ньому чергами та мінімізувати можливі відмови в обслуговуванні.

Ключові слова: активне управління чергами; управління перевантаженням; розподіл ресурсів; запобігання перевантаження; пропускна здатність; інтерфейс маршрутизатора; телекомунікаційна мережа; якість обслуговування.

\section{МЕТОД ПЛАНИРОВАНИЯ И АКТИВНОГО УПРАВЛЕНИЯ ОЧЕРЕДЯМИ НА ИНТЕРФЕЙСАХ МАРШРУТИЗАТОРОВ ТЕЛЕКОММУНИКАЦИОННЫХ СЕТЕЙ}

Предметом исследования в работе является метод планирования и активного управления очередями на интерфейсах маршрутизаторов телекоммуникационных сетей. Целью работы является разработка и совершенствование метода, связанного с оптимизацией процессов управления очередями на интерфейсах маршрутизаторов телекоммуникационных сетей и ориентированного на повышение показателей уровня качества обслуживания. В работе решаются оптимизационные задачи управления перегрузками, распределения ресурсов и предотвращения перегрузок на интерфейсах маршрутизаторов телекоммуникационных сетей в рамках двухэтапного метода расчёта. Методы исследования основаны на результатах аналитических расчетов, полученные в ходе использования пакета Optimization Toolbox среды Мatlab. При этом в ходе совершенствования метода управления очередями на интерфейсах маршрутизаторов телекоммуникационных сетей использовался аппарат математического программирования, содержащий функции линейного программирования. Результаты: получен усовершенствованный метод планирования и активного управления очередями на интерфейсах маршрутизаторов телекоммуникационных сетей с согласованным, последовательным и двухэтапным решением таких интерфейсных задач как управление перегрузками (Congestion Management), распределение пропускной способности интерфейса маршрутизатора (Resource Allocation) и предотвращения перегрузки (Congestion Avoidance). Выводы: применение предложенного метода планирования и активного управления очередями позволило достичь согласованного решения задач Congestion Management, Resource Allocation и Congestion Avoidance. В ходе решения оптимизационной задачи Congestion Management, которая условно относилась к первому этапу расчетов, удалось достичь оптимальной агрегации и распределения потоков пакетов по сформированным на интерфейсе маршрутизатора очередям на основании соизмеримости значений их классов. При решении оптимизационных задач Resource Allocation и Congestion Avoidance, которые относились ко второму этапу расчетов, удалось достичь оптимального распределения пропускной способности интерфейса маршрутизатора между сформированными на нем очередями и минимизировать возможные отказы в обслуживании.

Ключевые слова: активное управление очередями; управление перегрузкой; распределение ресурсов; предотвращение перегрузки; пропускная способность; интерфейс маршрутизатора; телекоммуникационная сеть; качество обслуживания.

\section{Бібліографічні описи / Bibliographic descriptions}

Лебеденко Т. М. Метод планування та активного управління чергами на інтерфейсах маршрутизаторів телекомунікаційних мереж. Сучасний стан наукових досліджень та технологій в промисловості. 2019. № 2 (8). С. 54-61. DOI: https://doi.org/10.30837/2522-9818.2019.8.054.

Lebedenko, T. (2019), "Method of scheduling and active queues management on routers interfaces of telecommunication networks", Innovative Technologies and Scientific Solutions for Industries, No. 2 (8), P. 54-61. DOI: https://doi.org/10.30837/25229818.2019.8.054. 